総合論文

\title{
アジン系複素環化合物の合成と

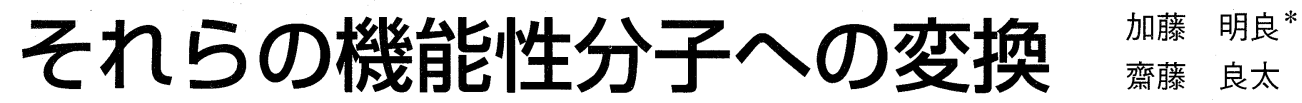

Synthesis of Azine-type Heterocyclic Compounds and Their Conversion into Functional Molecules

Akira Katoh* and Ryota Saito

\begin{abstract}
We have focused on the synthesis of azine-type heterocyclic compounds and their conversion into useful functional molecules. In this article, the following points were reviewed. 1) 6-Amino-2, 3-dimorpholinoquinoxalines bearing the amino acid residues at $\mathrm{C}-6$ position were found to be highly-sensitive fluorescent chiral derivatization reagents. 2) A new tripodal heterocyclic hexadentate ligand, in which three sets of 3-hydroxy-4 $(1 H)$-pyridinone and ethyleneoxy chain are linked to tris(carboxyethoxymethyl)ethane was synthesized. The allosteric binding of alkali metal ions to a pseudocryptand formed by the ligand and $\mathrm{Ga}$ (III) was discussed. 3) Hydroxyazine-type linear and cyclic hexapeptides were newly synthesized. The iron(III) complex-forming tendency, the absolute configuration, the stability constant, the iron(III) removal from human transferrin, and the growth-promotion activity were discussed. 4) Oxovanadium complexes of 3-hydroxy-4 $(1 H)$-pyridinones were synthesized. The spectroscopic characterization of the complexes was carried out on the basis of ${ }^{1} \mathrm{H}^{-},{ }^{51} \mathrm{~V}-\mathrm{NMR}$, IR, UV-VIS, FAB MS, ESI MS and ESR spectra, and cyclic voltammetry (CV). Further, an extremely high insulin-mimetic activity of bis (1, 4-dihydro-2-methyl-1-phenyl-4-thioxo-3-pyridinolato) zinc (II ) complex was also discussed.

Key words: 6-aminoquinoxaline, fluorescent chiral derivatization reagent, allosteric binding, hexapeptide, iron(III) complex, growth-promotion activity, oxovanadium complex, zinc(II) complex, insulin-mimetic activity
\end{abstract}

はじめに

当研究室では, ここ十数年来, アジン系複素環化合物 の化学療法剤を含む機能性分子への变換を中心に研究を 行っている。本論文では, 我々の最近の研究内容を中心 に紹介したい。

\section{6-アミノキノキサリン類の高感度蛍光キラル誘導 体化試薬への応用}

近年，多岐にわたる病気に対し，様々な薬物が開発さ れてきたが，その薬物による治療効果を最大限に引き出 すには，生体内の成分分析を高感度に行うことにより， 病状を総合的に把握する必要がある。このニーズに応え る1つの手段として, 蛍光 HPLC 法が注目されてい る1-3)。また，1990年までに開発された医薬品のうち， 約 40\%が不斉炭素をもっていたにもかかわらず，約 $12 \%$ し単一のエナンチオマーとして市販されていな かった。しかし，エナンチオマー間で薬理活性や副作用

\section{$*$ 成蹊大学工学部応用化学科}

* Department of Applied Chemistry, Faculty of Engineering, Seikei University
が全く異なる事例がいくつも見出されたため，単一の工 ナンチオマーの合成が非常に重要になってきた。これに 伴い, エナンチオマーの高感度分析を可能にする蛍光キ ラル誘導体化試薬の開発も活発に行われている。スキー ム 1 には, HPLCによる蛍光ラベル誘導体化試薬を用い たエナンチオマーの高感度分析を模式的に示した。これ までに, 蛍光キラル誘導体化試薬に関する研究が数多く なされているが4-18), 市販されているものは図 1 に示し た APy ${ }^{17)}$ やAP-OTf ${ }^{10)}$ など少数に限られている。

当研究室では，2,3-ジモルホリノー6ーアミノキノキサ リン 1 が強い蛍光を発すること, および長鎖カルボン酸 の新しい高感度蛍光誘導体化試薬になり得ることを報告 した ${ }^{19)}$ 。その後, 図 2 に示したキノキサリン誘導体 2,3 が長鎖脂肪酸やアミン類の高感度蛍光誘導体化試薬にな り得ることも明らかにした20)。ここでは, キラル蛍光誘 導体化試薬の合成とそれらを用いたエナンチオマーの高 感度分析について述べる。

キラル誘導体化試薬としては, L-Pro, L-Ala, L-Phe 残基を連結したキノキサリン 4 と活性基としてブロモア セチル基をもつキノキサリン 5 を合成した。化合物 5 を 用いた (土)-ナプロキセン，(土)-イブプロフェン， 


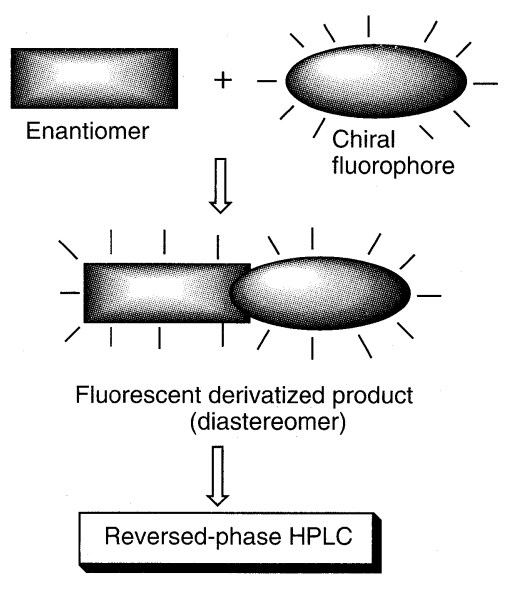

Scheme 1 Highly-sensitive detection of enantiomers with fluorescent chiral derivatization reagent.
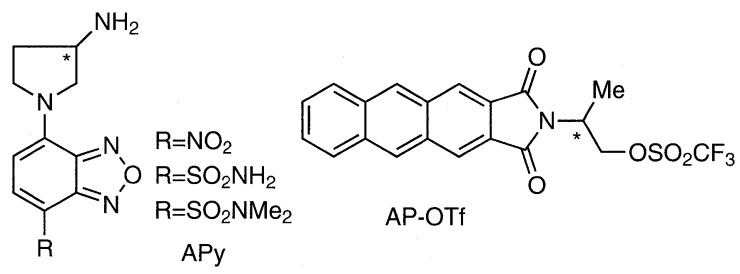

Fig. 1 Commercially available fluorescent chiral derivatization reagents.<smiles>[R]C(=O)OCc1ccc2nc(N3CCOCC3)c(N3CCOCC3)nc2c1</smiles><smiles>COc1ccc2cc(C#CC(=O)Cl)c(=O)n(C)c2c1</smiles>

Fig. 2 Fluorescent quinoxalines.

$( \pm)$-フェニルプロピオン酸の誘導体化は, $\mathrm{KHCO}_{3}$ と 18 -クラウン -6 の存在下 ${ }^{21)}$ で行いジアステレオマー6 を得た。また，化合物 4 を用いた誘導体化は，2, 2'-ジ ピリジルジスルフィドと $\mathrm{Ph}_{3} \mathrm{P}$ 存在下 ${ }^{22)}$ で行いジアステ レオマー 7 を得た(スキーム2)。

誘導体化生成物であるジアステレオマーはいずれも強 い蛍光を発し，かつ ${ }^{1} \mathrm{H}$ NMR において $1: 1$ のピーク比 でシグナルが観測されたことから，ジアステレオマー間 で反応性に差がないこともわかった。ジアステレオマー 6, 7 の蛍光スペクトルを $\mathrm{MeCN}$ 中で測定した結果，励 起波長を $370 \mathrm{~nm}$ とした時蛍光極大波長は約 $440 \mathrm{~nm}$ と なり，すべての誘導体で $70 \mathrm{~nm}$ 近いストークスシフト が観測された。さらに，ジアステレオマーの各種溶媒中 での蛍光スペクトルを測定した結果, 非プロトン性溶媒 である $\mathrm{MeCN}$ に比べ，プロトン性溶媒である $\mathrm{MeOH} や$ 水中では著しい蛍光強度の減少が起った。この結果を踏 まえ，逆相 HPLCにおける移動相には $\mathrm{MeCN}$ の比率の 高い溶媒を選択することにした。

得られたジアステレオマーについて，順相および逆相
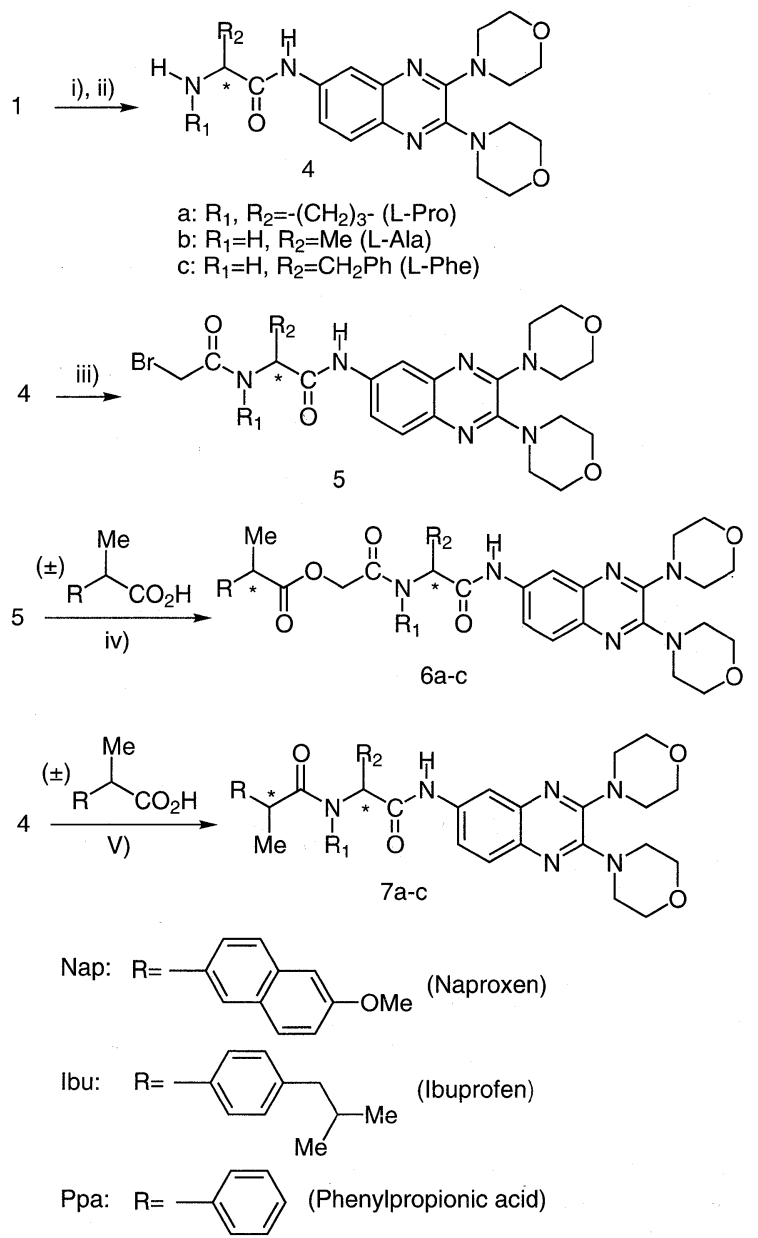

Scheme 2 Reagents and conditions: i) $\mathrm{N}$-benzyloxycarbonylamino acid, WSC-HOBt, dry DMF$\mathrm{CH}_{2} \mathrm{Cl}_{2}$; ii) $\mathrm{H}_{2} / 10 \% \mathrm{Pd}-\mathrm{C}, \mathrm{MeOH}$; iii) $\mathrm{BrCH}_{2} \mathrm{CO}_{2} \mathrm{H}$, DCC, dry DMF; iv) 18-crown-6, $\mathrm{KHCO}_{3}, \mathrm{MeCN}$; v) 2, 2'-dipyridyl disulfide, $\mathrm{Ph}_{3} \mathrm{P}, \mathrm{CH}_{2} \mathrm{Cl}_{2}$.

カラムを用いた蛍光検出器付 HPLCにおける分離度を 種々の条件下で測定した。まず，ジアステレオマー6を 逆相カラム Finepak SIL $\mathrm{C}_{18} \mathrm{~S}$ を用いて分離を試みたが, うまく分離することはできなかった。そこで，ジアステ レオマー6を順相系光学活性カラム CHIRALCEL OD を用い, hexane-EtOH- $\mathrm{Me}_{2} \mathrm{NH}(80: 20: 0.03)$ を移動相 として用いたところ, 分離度 $\mathrm{Rs}$ は化合物 $6 \mathrm{a}(\mathrm{PPa})$ で $1.26,6 \mathrm{~b}(\mathrm{PPa})$ で 0.87 (分離度が 1.5 以上で，完全にベー スライン分離) となり，完全には分離できなかった。最 後に，ジアステレオマー7を逆相カラム Finepak SIL $\mathrm{C}_{18} \mathrm{~S}$ を用い, $\mathrm{MeCN}-\mathrm{H}_{2} \mathrm{O}(80: 20$ or 70 : 30)を用いて分 離度を測定した。アミノ酸残基としてはL-Proの場合が 最も分離度が大きくなり，図３に示したように各ピーク を完全に分離・検出することができた。この場合の分離 度 Rs は，7a(Nap)で 2.20, 7a(lbu)で 2.82, 7a(PPa)で 2.02 であった。これは, ジアステレオマー7のほうが 6 に比べ，2つの不斉炭素がより接近しているためだと思 われる。ジアステレオマーの検出限界は，S/ $\mathrm{N}$ 比を 5 
としたとき, $5 \mathrm{pmol} / 10 \mu \mathrm{l}$ injection volume となり, か なり高感度で検出できることがわかった。

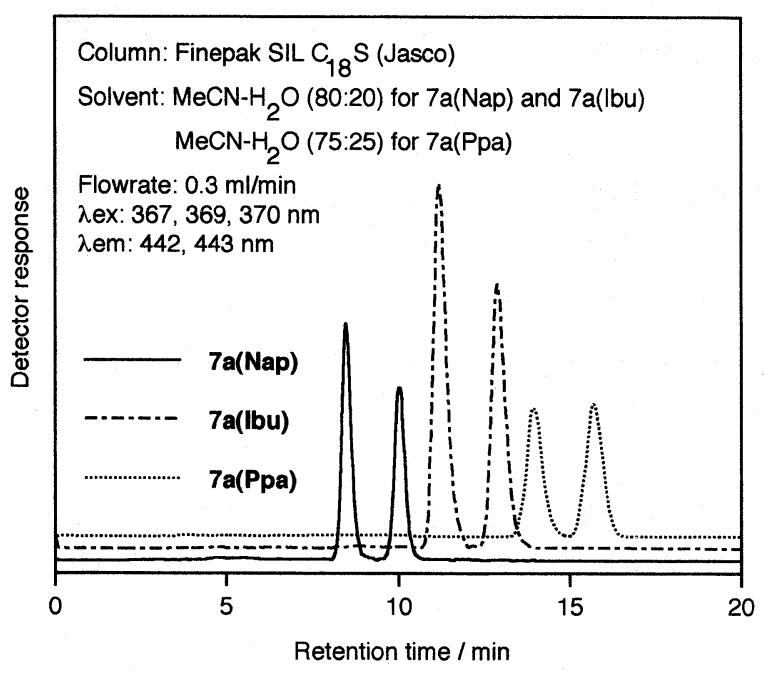

Fig. 3 Chromatograms of the derivatized products $7 a(N a p)$, $7 \mathrm{a}(\mathrm{lbu})$ and $7 \mathrm{a}(\mathrm{Ppa})$.

\section{3-ヒドロキシー $\gamma$-ピリドンの $\mathrm{Ga}(\mathrm{III})$ 錯体による アルアルカリ金属イオンの協同イオン認識}

生体内の化学反応を司っている酵素の中には, “アロ ステリック効果”を示すものがある。この酵素は，この ままでは基質を認識できないが, 基質結合部位とは異 なった部位にエフェクターが作用すると, 基質結合部位 の構造が変化し，はじめて基質を認識することができ $る^{23,24)}$ 。このアロステリック効果を人工的に再現する試 みが, 鍋島らの先駆的な研究 ${ }^{25)}$ の後も活発に行われて いる。例えば，ビピリジン ${ }^{26)}$ やカテコール27)を二座配 位子とした金属錯体が形成する擬クラウンエーテルによ るアルカリ金属イオンの認識や, 配位子 Lとして $\beta$-ジ ケトン ${ }^{28)}$ やカテコール29) や8-ヒドロキシキノリン ${ }^{30)}$ か らなる $\mathrm{M}_{2} \mathrm{~L}_{3}(\mathrm{M}=\mathrm{Fe}(\mathrm{II}), \mathrm{Ti}(\mathrm{IV}), \mathrm{Ga}(\mathrm{III}))$ 配位モードの 擬クリプタンドによるアルカリ金属イオンの認識などが 挙げられる。これに対して, $N$-ピボットの三方向性六 座配位子に関しては，配位子 2,2 -ビピリジンの Fe(II) 錯体が形成する擬クリプタンドによる $\mathrm{Cs}^{+}$イオンの認 識が報告されているに過ぎない31)。

当研究室ではこれまでに, ヒドロキシアジン系複素環 を含む様々な三方向性六座配位子の合成と遷移金属錯体 の機能評価を行ってきた ${ }^{32)}$ 。この中で，アロステリック 効果を人工的に再現する研究として, $N$-ヒドロキシピ ラジノンと比較的フレキシブルなホモトリオキサカリッ クス[3]アレーンからなる人工ホストの $\mathrm{Ga}$ (III) 錯体に よるアンモニウム塩の協同認識を報告した ${ }^{33)}$ 。ここで は，これまでに報告例のない $C$-ピボットの三方向性六 座配位子の $\mathrm{Ga}$ ( III) 錯体によるアルカリ金属イオンの協

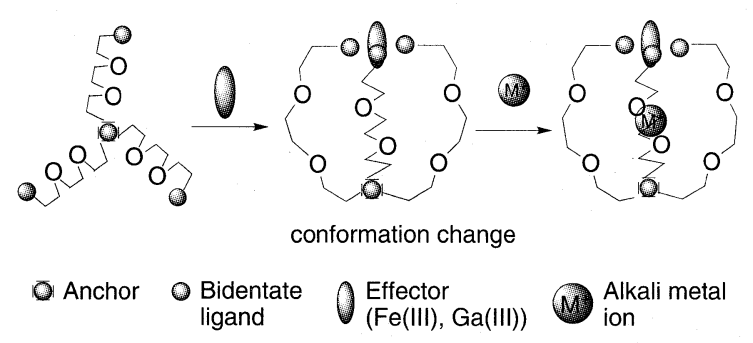

Fig. 4 A schematic presentation of allosteric binding of alkali metal ions.

同イオン認識について述べる ${ }^{34)}$ 。

図 4 には，アンカー部位とエチレンオキシ鎖と複素環 系二座配位子からなる三方向性人工ホス卜分子と金属イ オンから形成される擬クリプタンドによるアルカリ金属 イオンの協同イオン認識を模式的に示した。このホスト 分子は,このままでは, フレキシブルな構造をとってお り，アルカリ金属イオンを取り込むことは困難であると 予想される。しかし, $\mathrm{Fe}(\mathrm{III}) や \mathrm{Ga}(\mathrm{III})$ イオンと六配位八 面体錯体を形成すると，ホスト分子のコンフォメーショ ンが大きく変化し, 擬クリプタンド様の三次元の空孔が 形成され, 各種イオンの取り込みが可能になると考 えた。
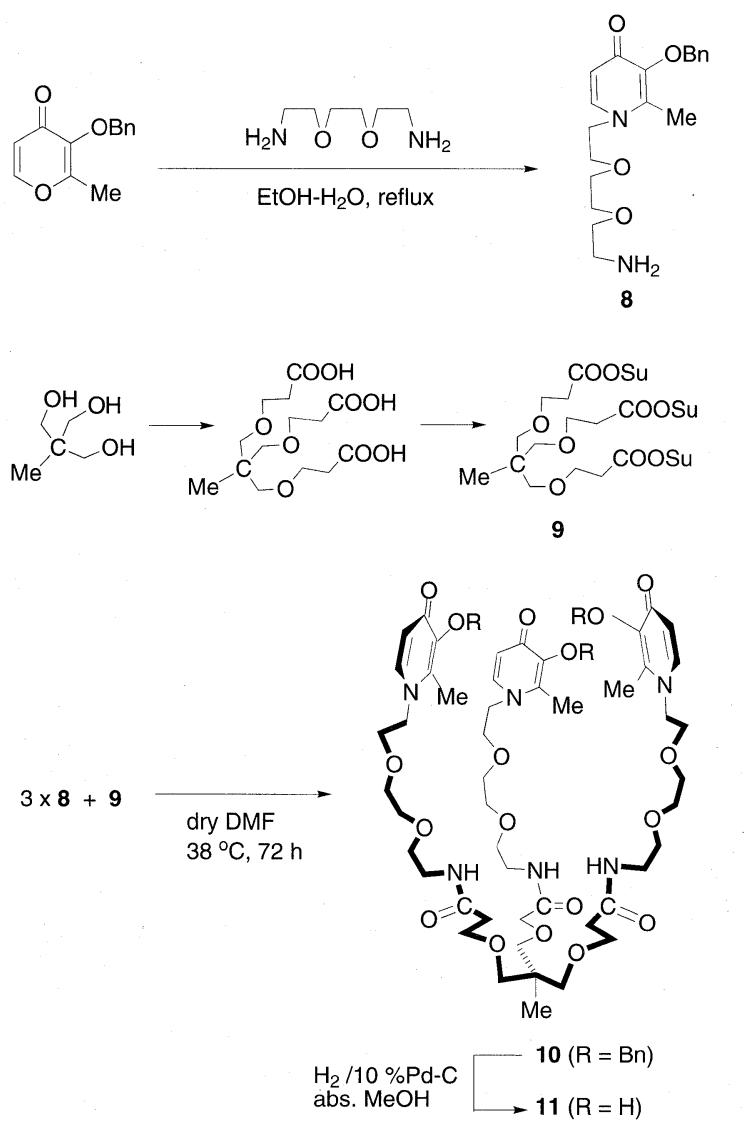

Scheme 3 Synthesis of tripodal hexadentate ligand 11.

3-ヒドロキシー $\gamma$-ピリドンを金属配位部位，エチレン オキシ鎖をスペーサー, トリス(カルボキシエトキシメ 
チル)エタンをアンカーにもつCーピボット三方向性ホス 卜分子 11 は, 活性エステル 9 に対して 3 当量のアミン 8 を反応させ ${ }^{35)}$, 得られたベンジル保護体 10 を接触還 元することにより合成した $($ スキーム 3)。人工ホスト 11 の溶液中のコンフォメーションを知るために, DMSO- $d_{6}$ 中での温度可変 ${ }^{1} \mathrm{H}$ NMR を測定した。1セッ トのシグナルが観測されたことから， $C_{3}$ 対称構造を とっていることがわかった。また, $20{ }^{\circ} \mathrm{C} ら 80{ }^{\circ} \mathrm{C}$ 温 度範囲でアミドプロトンの化学シフトの温度依存係数を 測定したところ， $-5.7 \times 10^{-3} \mathrm{ppm} \mathrm{deg}^{-1}$ となった(図 5)。一般に強い水素結合を形成した場合には $-3 \times 10^{-3}$ ppm deg ${ }^{-1}$ 以下となることから ${ }^{36)}$, この人工ホスト 11 は, DMSO- $d_{6}$ 中では特定の強い水素結合を形成してい ないことがわかった。

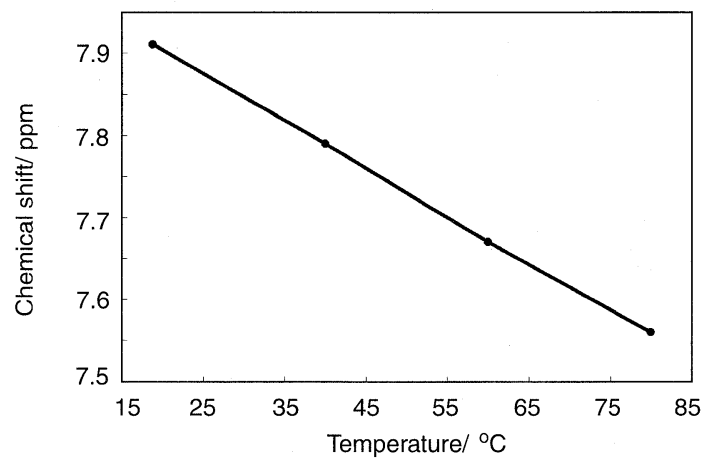

Fig. 5 The temperature dependence of the amide proton chemical shift..

次に，人工ホストの $\mathrm{Fe}(\mathrm{II})$ 錯体形成能を評価した。3 章と内容が重複するので詳しい記述は省略するが，1）人 工ホスト 11 は, $\mathrm{Fe}$ (III) と安定な $1: 1$ 錯体を形成する $\left(\lambda \max 460 \mathrm{~nm}, \varepsilon 5100 \mathrm{M}^{-1} \mathrm{~cm}^{-1}\right.$ at pH 7.43)こと, 2) ESI $\mathrm{MS}$ で $m / z 1126$ が観測され錯体の $\mathrm{pH}$ 調整に用いた $\mathrm{NaOH}$ の $\mathrm{Na}^{+}$が包接されること，3) 錯体の相対安定度 定数は $\log \mathrm{K}$ 值で 32.9 となり, かなり鉄を強く保持す ることなどが明らかとなった。 Fe (III) は常磁性である ため，NMRを測定することはできない。そこで， $\mathrm{Fe}$ (III) とほほ同じイオン半径をもち, しかも反磁性で ある $\mathrm{Ga}(\mathrm{III})$ を用いてアルカリ金属イオンの協同イオン 認識能を評価した。

$\mathrm{Ga}$ (III) 錯体は， $\mathrm{CDCl}_{3}$ 中，人工ホスト 11 と等モルの $\mathrm{Ga}(\mathrm{acac})$ 3を反応させることにより調製した ${ }^{33)} 。$ $1: 1 \mathrm{Ga}(\mathrm{II})$ 錯体の形成は, 1 位の $\mathrm{N} の$ 隣のメチレンプ ロトンと 3 -ヒドロキシー $\gamma$-ピリドン環の 5,6 位のオレ フィンプロトンが低磁場シフトしたこと，㧠よび FAB $\mathrm{MS}$ で $m / z$ が $1118[\mathrm{Ga}(\mathrm{II}) \text { 錯体 }+\mathrm{H}]^{+}$に観測されたこと から決定した。また， $\mathrm{Ga}$ (III)錯体の形成に伴って，す ベてのシグナルがブロードニングしたことから，錯形成 によりフレキシビリティーが低下することもわかった。
人工ホスト 11 の $\mathrm{CDCl}_{3}$ 溶液にアルカリ金属を添加し て， ${ }^{1} \mathrm{H}$ NMR を測定したが，全くシグナルに変化は見 られなかった。これに対して，人工ホスト-Ga（III)錯体 の場合は, 化学シフトに変化が見られ, 協同イオン認識 が示唆された。 $\mathrm{Ga}(\mathrm{III})$ 錯体が $\mathrm{Na}^{+}$や $\mathrm{K}^{+}$イオンに対して $1: 1$ 錯体を形成することは, 図 6 に示したモル比プ ロットから確認した。また, Benesi-Hildebrand 式 ${ }^{377}$ か ら会合定数を算出したところ, $\mathrm{Na}^{+}$イオンに対しては $5.9 \times 10^{2}, \mathrm{~K}^{+}$イオンに対しては $5.8 \times 10^{2}$ となり， K-[2.2.2]クリプタンドに比べかなり小さな值であった。 これは，3ーヒドロキシー $\gamma$-ピリドンが $\mathrm{Ga}(\mathrm{III})$ と六配位 八面体錯体を形成した場合，3本のエチレンオキシ鎖は 発散するようなコンフォメーションをとらざるを得ず, 理想的なクリプタンド様三次元空孔を構築できなかった ためと思われる。さらに，アルカリ金属を添加した場 合，3-ヒドロキシー $\gamma$-ピリドン近傍のプロトンシグナル のみが大きく低磁場シフトしたことから，図７に示した ように,アルカリ金属イオンは, 空孔の上部で認識され ていると推測している。

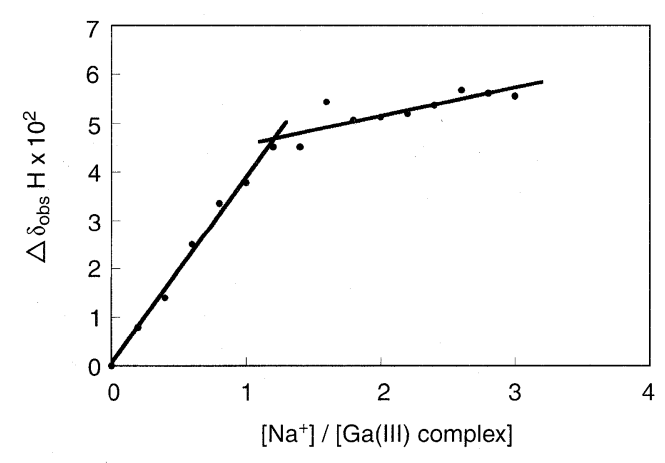

Fig. 6 Plots of $\Delta \delta_{\text {obs }} \mathrm{H}$ versus the molar ratio of $\mathrm{Na}^{+}$ ion to $11-\mathrm{Ga}$ (III) complex.

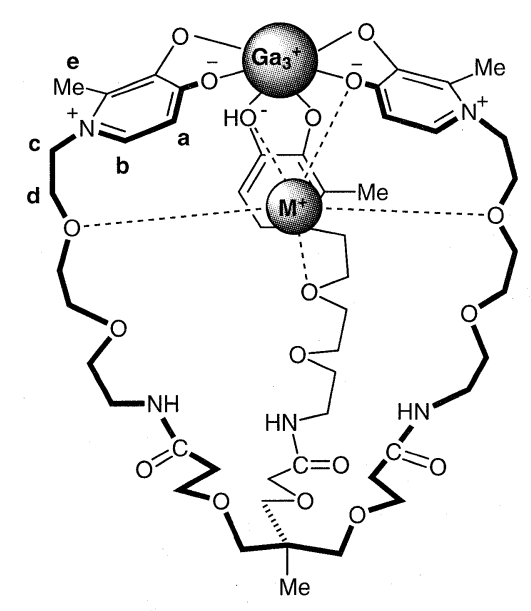

Fig. 7 A possible structure of allosteric binding of alkali metal ions by pseudocryptand.

以上のように，本研究によってC-ピボットの三方向 性六座配位子の $\mathrm{Ga}$ （III）錯体によるアルカリ金属イオン 
の協同イオン認識を初めて明らかにすることができた。

\section{3. ペプチド性鎖状および環状ジアジン系六座配位 子 $-\mathrm{Fe}(\mathbb{I I})$ 錯体の諸機能}

鉄は生命維持に必須の元素であり，地核表面に 4 番目 に豊富に存在するため，その利用は一見簡単そうにみえ る。しかし，好気性の条件下では，鉄は難容性の $\mathrm{Fe}(\mathrm{OH})_{3}$ などの形で存在するため, 生物は鉄を取り込 む手段をもつ必要があった。微生物は, 鉄イオン輸送体 (シデロフォア)を分泌し，錯形成により鉄を可溶化し， 細胞内に取り达む。シデロフォアは，ヒドロキサム酸型 とカテコール型に大別される ${ }^{38-41)}$ 。このうち，天然のト リヒドロキサム酸であるデスフェリオキサミン B (DFB) は, 鉄過剩症の唯一の化学療法剤として使用さ れている。例えば，クーリー貧血症の患者は，へモグロ ビンの $\beta$-鎖の遺伝的欠陥により，正常に酸素を運搬す ることができない。この病気の治療法としては，図８に 模式的に示したように，長年にわたって輸血をする必要 があり, その結果, 体内の藏器に鉄が過剩に蓄積し, 機 能不全を起こし，結果として死に至ることがある。この 過剩な鉄を除去するために，デスフェリオキサミン B (商品名：デスフェラール)が市販されている。しかしな がら，デスフェラールは経口投与できない22)，血漿中で の半減期が短い ${ }^{43)}$, 敗血症などの副作用がある ${ }^{44)}$ など の問題点があり，新しい治療薬の開発が望まれている。

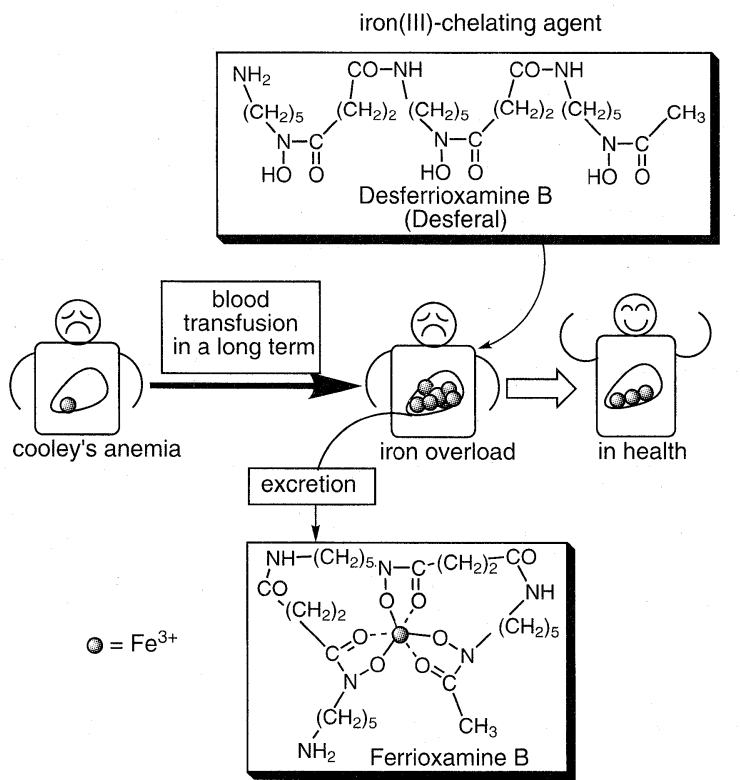

Fig. 8 Treatment of the iron overload disease.

当研究室では，これまでに $N$-ヒドロキシアミド結合 を含むアジン系複素環化合物を合成し, 新しい鉄過剩症 治療薬としての可能性を検討してきた。詳しい内容につ いては，本誌の総合論文 ${ }^{45)}$ を参考にしていただきたい。 ここでは，その後に合成した，3-ヒドロキシー $\gamma$-ピリド
ン46)または $N$-ヒドロキシ-2 $(1 H)$-ピリミジノン ${ }^{47)}$ を二 座配位子として含む鎖状㧍よび環状のペプチド性六座配 位子 $\mathrm{Fe}(\mathrm{II})$ 錯体の諸性質について述べることにする。

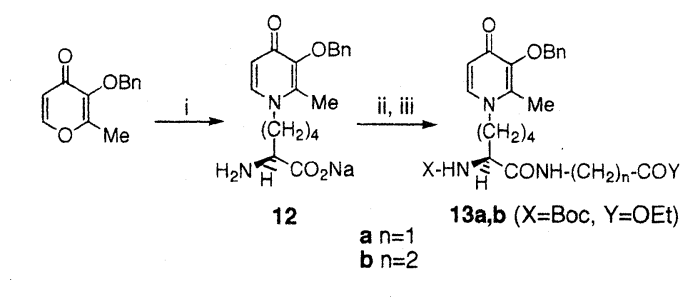

$14 a, b(X=B O C, Y=O H) \stackrel{\text { iv }}{\longleftarrow} 13 a, b \stackrel{v}{\longrightarrow} 15 a, b(X=T F A \cdot H, Y=O E t)$

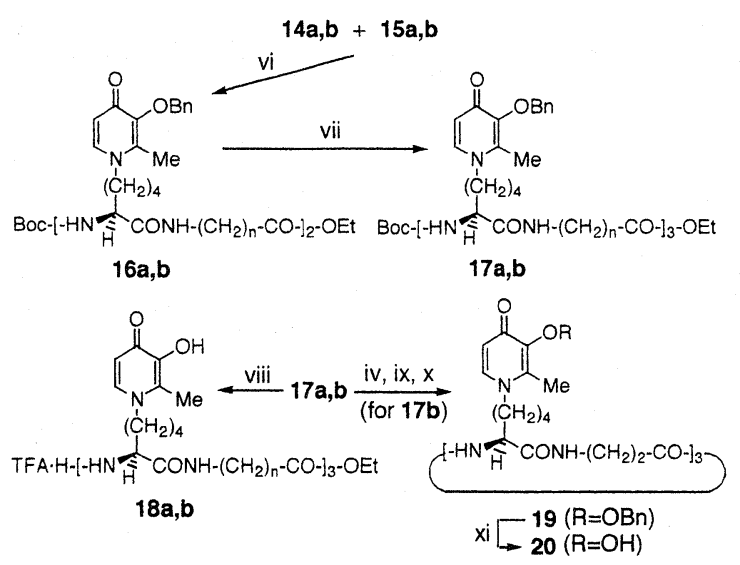

Scheme 4 Reagents and conditions: i) L-lysine, $\mathrm{NaOH}$, $\mathrm{H}_{2} \mathrm{O}-\mathrm{EtOH}$; ii) $\mathrm{Boc}_{2} \mathrm{O}$, dioxane; iii) $\mathrm{HCl}$. $\mathrm{H}_{2} \mathrm{~N}-\left(\mathrm{CH}_{2}\right)_{\mathrm{n}}-\mathrm{CO}_{2} \mathrm{Et}, \mathrm{N}$-methylmorpholine, WSC $\cdot \mathrm{HCl}-\mathrm{HOBt}, \mathrm{CH}_{2} \mathrm{Cl}_{2}$; iv) $1 \mathrm{M} \mathrm{NaOH}$, $\mathrm{MeOH}$; v) TFA, $\mathrm{CH}_{2} \mathrm{Cl}_{2}$; vi) $\mathrm{N}$-methylmorpholine, WSC $\cdot \mathrm{HCl}-\mathrm{HOBt}, \mathrm{CH}_{2} \mathrm{Cl}_{2}$; vii) $14 \mathrm{a}, \mathrm{b}$, TFA, $\mathrm{CH}_{2} \mathrm{Cl}_{2}$, and then $\mathrm{N}$-methylmorpholine, $\mathrm{CDI}, \mathrm{DMF}$; viii) $\mathrm{H}_{2} / 10 \% \mathrm{Pd}-\mathrm{C}, \mathrm{MeOH}$, and then TFA, $\mathrm{CH}_{2} \mathrm{Cl}_{2}$, ; ix) WSC $\cdot \mathrm{HCl}-\mathrm{HOSu}$, DMF; x) TFA, $\mathrm{CH}_{2} \mathrm{Cl}_{2}$, and then pyridine (high dilution); xi) $\mathrm{H}_{2} / 10 \% \mathrm{Pd}-\mathrm{C}, \mathrm{MeOH}$.

3-ヒドロキシー $\gamma$-ピリドンを含む鎖状および環状へキ サペプチドの合成手順をスキーム 4 に示した。アミノ酸 側鎖の $\mathrm{N}$ を複素環の環構成元素とした化合物 12 にグリ シンおよび $\beta$-アラニンをカップリングさせジペプチド 13 を合成した。ジペプチド 13 から酸成分 14 とアミン成分 15 を調製し，両者をカップリングさせテトラペプチド 16 を得た。テトラペプチド 16 の脱 Boc 化により得られ たアミン成分とジペプチド酸成分 14 とのカップリング によりへキサペプチド 17 を得た。へキサペプチド 17 の 脱ベンジル化, 脱 Boc 化により, 鎖状へキサペプチド 18 を得た。-Lys- $\beta$-Ala-を繰り返し単位とする環状へキ サペプチド 20 は問題なく合成できたが，-Lys-Gly-を 含む環状ぺプチドは合成できなかった。また，図 9 に は，1-ヒドロキシー2 $(1 H)$-ピリミジノンを含む鎖状 21 および環状へキサペプチド 22 の構造を示した。

まず，ヘキサペプチドの $\mathrm{Fe}$ (III) 錯体形成能を調べた。 鎖状へキサペプチド $18 \mathrm{~b} と \mathrm{Fe}(\mathrm{III})$ の $1: 1$ 混合水溶液の 


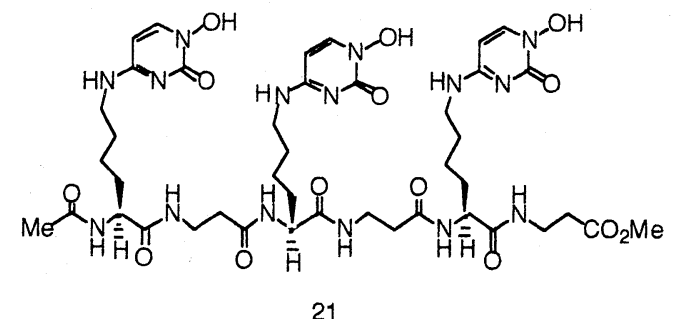

21

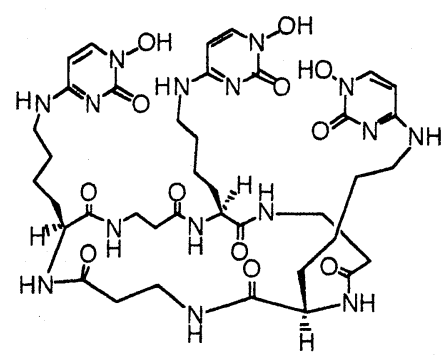

22

Fig. 9 Linear and cyclic hexapeptides with 1-hydroxy-2(1H)-pyrimidinone.

UV-VIS スペクトルを測定した。図 10 に示したように， 460-520 nm の領域で LMCT に基づく特徴的な吸収が 観測された。 $\mathrm{pH}$ の上昇とともに，吸光度が増加しなが ら $\lambda \max$ が短波長シフトしたことから，図 11 に示した ように, $\mathrm{Fe}(\mathbb{I I}): 3$-ヒドロキシー $\gamma$-ピリドン $1: 1 \rightarrow 1: 2$ $\rightarrow 1: 3$ 錯体が形成されていることがわかった。 $\mathrm{pH} 7.47$ で $\lambda \max$ は $460 \mathrm{~nm}, \varepsilon$ は 4300 となり，3-ヒドロキシー $4(1 H)$-ピリジノン $-\mathrm{Fe}(\mathrm{III}) 3: 1$ 錯体 ${ }^{48)}$ との比較抢よびモ ル比プロットの結果から, $18 \mathrm{~b}$ は $\mathrm{Fe}(\mathrm{II})$ と安定な分子 内 $1: 1$ 錯体を形成することがわかった。鎖状 18a 㧍よ び環状へキサペプチド 20 についても，同様な結果を得

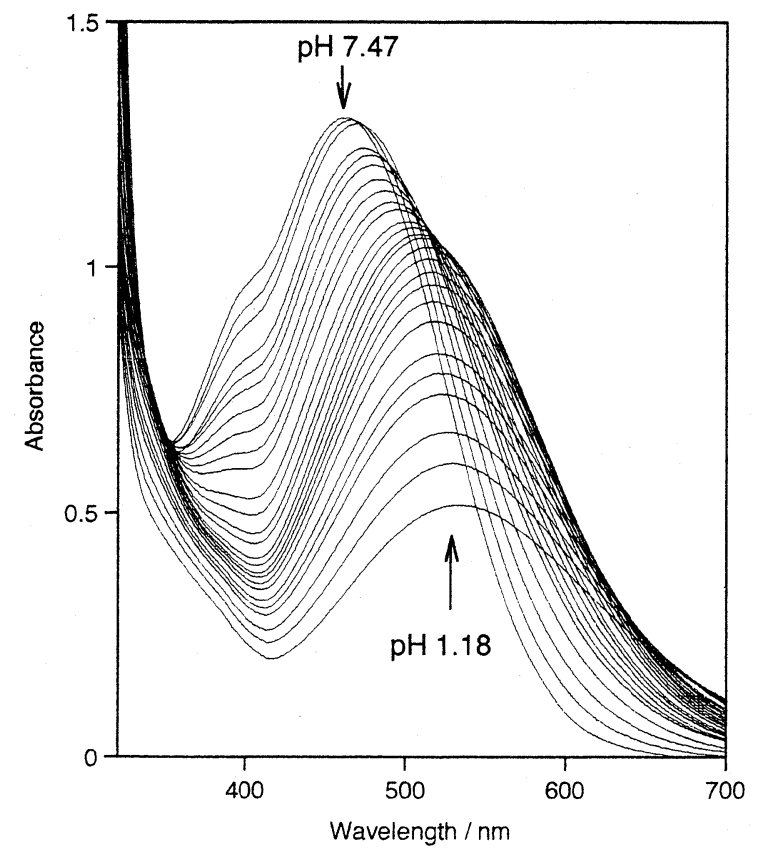

Fig. 10 Spectral change of $18 \mathrm{~b}$-iron(II) complex in aqueous solution under various $\mathrm{pH}$ conditions.

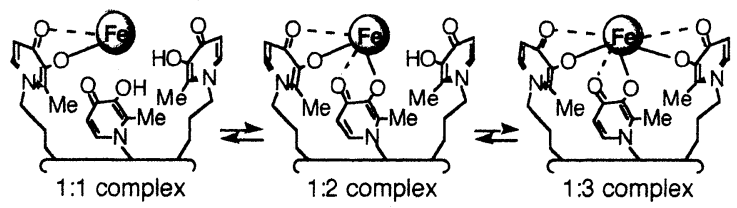

Fig. 11

た。また，ピリミジノン含有へキサペプチド $21 ， 22 も$ $\mathrm{Fe}$ (III) と $1: 1$ 錯体を形成することがわかった。

18b-Fe (III) 錯体の場合, pH 2.36 から 2.93 の範囲で, $515 \mathrm{~nm}$ に等吸収点が観測された。これは，式 1 に示す 平衡を反映している。

$$
\mathrm{Fe}(\mathrm{L})+\mathrm{H}^{+} \rightleftarrows \mathrm{Fe}(\mathrm{HL})^{+}
$$

ここで, $\mathrm{Fe}(\mathrm{L})$ は $1: 1$ 錯体であり, $\mathrm{Fe}(\mathrm{HL})^{+}$は分子 中の 3 -ヒドロキシ $-\gamma$-ピリドン配位子 3 個中 1 個がプロ トン化した錯体である。式 1 はまた，式 2 のように表さ れる。

$$
K_{\mathrm{Fe}(\mathrm{HL})}=\left[\mathrm{Fe}(\mathrm{HL})^{+}\right] /[\mathrm{Fe}(\mathrm{L})]\left[\mathrm{H}^{+}\right]
$$

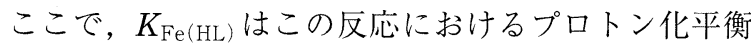
定数である。さらに, 得られたスペクトルデー夕は, 式 3 のような Schwarzenbach 式を用いて解析できる。

$$
A_{\mathrm{obs}}=\left(A_{0}-A_{\mathrm{obs}}\right) /\left[\mathrm{H}^{+}\right] K_{\mathrm{Fe}(\mathrm{HL})}+\varepsilon_{\mathrm{Fe}(\mathrm{HL})} \mathrm{c}_{\text {total }}
$$

ここで， $A_{\text {obs }}$ はそれぞれの $\mathrm{pH}$ における $460 \mathrm{~nm}$ での 吸光度, $A_{0}$ は $\mathrm{pH} 7.47$ における $460 \mathrm{~nm}$ での吸光度, $\left.\varepsilon_{\mathrm{Fe}(\mathrm{HL})}\right)$ はモノプロン化種の $460 \mathrm{~nm}$ でのモル吸光係数 である。

解析結果から，図12のような直線が得られ，傾きと 切片から $K_{\mathrm{Fe}(\mathrm{HL})}$ と $\varepsilon_{\mathrm{Fe}(\mathrm{HL})}$ 算出した。その結果, $\varepsilon_{\mathrm{Fe}(\mathrm{HL})}$ は 2800 となり，1 個の3-ヒドロキシー $\gamma$-ピリドン配位 子が $\mathrm{Fe}($ III $)$ に配位した時の $\varepsilon$ 増加分は 1400 であり，3 個目の配位子が $\mathrm{Fe}$ (III) に配位した時の増加分 1500 とほ

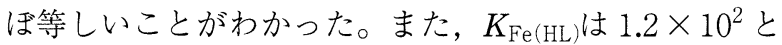
なり，既に報告されているぺプチド性トリヒドロキサム 酸- $\mathrm{Fe}$ (III) 鉄錯体 ${ }^{49)}$ よりもかなり小さい価であった。こ れらのデータから, -Lys- $\beta$-Ala- 繰り返し単位は, 安 定なへキサペプチド：Fe（III）1：1 錯体を形成するに十 分なスペースを提供していることが示唆された。

$\mathrm{Fe}(\mathrm{III})$ 錯体の相対安定度定数を，EDTA との鉄交換 反応をもとに算出した結果，18a- $\mathrm{Fe}$ (III) 錯体は $\log \mathrm{K}$ 值で 31.6，18b-Fe (III) 錯体は 33.4，20-Fe（而) 錯体は 31.7 となり, 天然のトリヒドロキサム酸である DFB $(\log$ $\mathrm{K}=30.5)^{50)}$ よりも大きな值であった。 $18 \mathrm{~b}-\mathrm{Fe}($ III $)$ 錯体 の安定度定数は, $18 \mathrm{a}-\mathrm{Fe}$ (III) 錯体より 2 桁程度大きく, ペプチド鎖長が鉄錯体の安定性に大きく影響しているこ とがわかった。また，一般的に鎖状に比べ環状の錯体の 


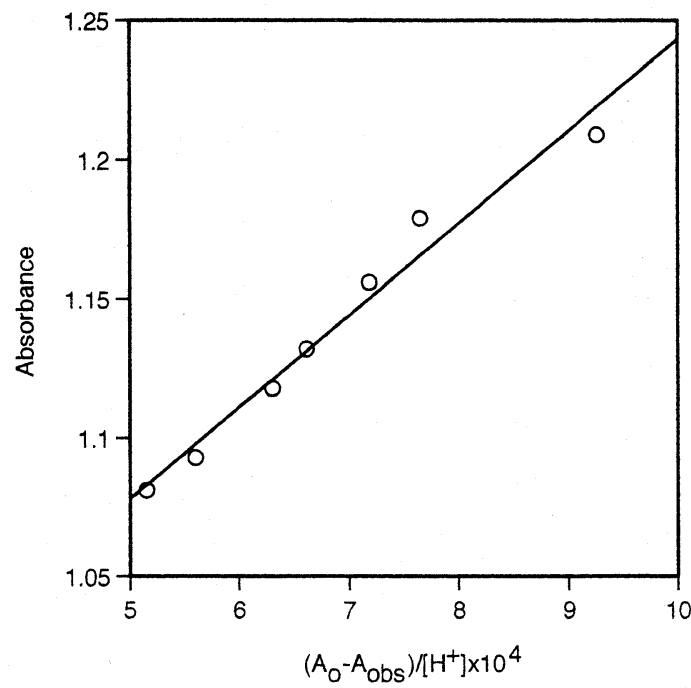

Fig. 12 The Schwarzenbach plot covering the $\mathrm{pH}$ range 2.36-2.93.

方が，キレート効果により大きな安定度定数が得られ る。しかしながら, 今回合成した錯体の安定度定数はほ ぼ等しかった。これは，ヘキサペプチドが環状構造をと るとかなりリジッドとなり，鉄をしっかりと保持できな いためだと推測している。

$\mathrm{Fe}$ (III) 錯体の絶対配置に関する知見を得るために， CD スペクトルを測定した(図 13)。鎖状へキサペプチド $18 \mathrm{a}-\mathrm{Fe}$ (III) 錯体は, $490 \mathrm{~nm}$ に負の，350 nm に正の コットン効果を示し， $\Delta$-体が優先的に存在することが わかった。また，環状へキサペプチド 20-Fe ( III) 錯体も $18 \mathrm{a}-\mathrm{Fe}$ ( III) 錯体と類似の CD スペクトルを示した。こ れに対して，18b-Fe (III) 錯体は逆の CD パターンを示

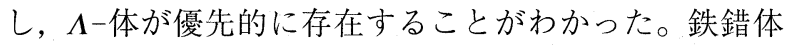
の絶対配置を規制する因子としてこれまでに1) 分子内 のアミノ酸残基の絶対配置, 2) 分子内の強い水素結合 ${ }^{51)}$, 3)アミノ酸残基の側鎖のかさ高さ52) などが報告されて いるが，今回のようにペプチド骨格を形成するアミノ酸 残基(Gly vs $\beta$-Ala)の相違で絶対配置が反転した例は初 めてである。

今回, 合成したへキサペプチドがヒトの鉄イオン輸送 タンパクであるトランスフェリンからどの程度鉄を除去 できるかを調べた。文献 ${ }^{53)} に$ 従って調製した鉄 2 個を 含むトランスフェリンの緩衝液に過剩のへキサペプチド を加え, $460 \mathrm{~nm}$ における吸光度の変化を追跡した。反 応開始 30 分後の鉄除去率を比較したところ, へキサペ プチド $18 b$ と 22 はいずれも天然の DFBより約 3 倍効 率良く鉄を除去できることがわっかた。さらに興味深い ことに，鎖状へキサペプチド 18b は 18aの 2 倍効率良 く鉄を除去できることがわかった。この違いは， $18 \mathrm{~b}-\mathrm{Fe}$ ( III ) 錯体が $\Lambda$-体を優先的にとるのに対し, $18 \mathrm{a}-\mathrm{Fe}$ (III) 錯体が $\Delta$-体を優先的にとることに起因して

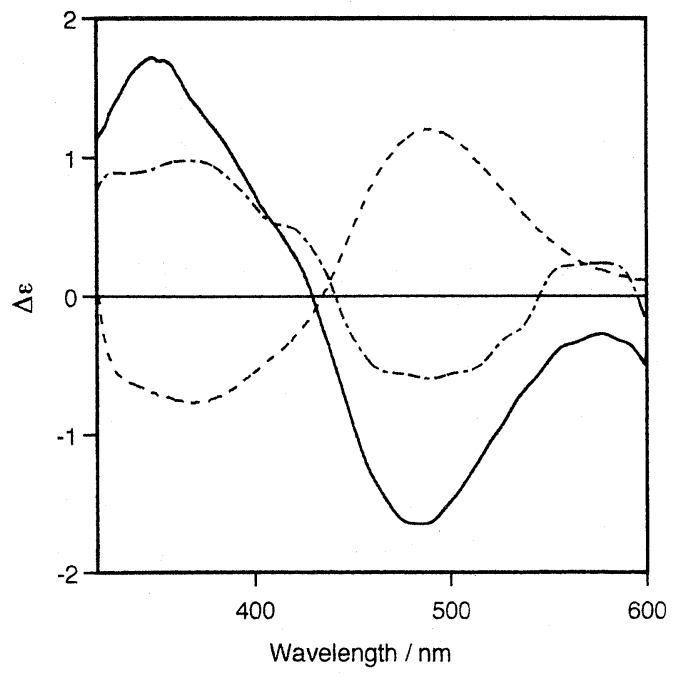

Fig. 13 CD spectra of iron(III) complexes in aqueous solution at $\mathrm{pH} 7.4 ;(-) ; 18 \mathrm{a}-\mathrm{iron}(\mathrm{III}) ;(----)$; 18b-iron(III); (----); 20-iron(III).

いると考えている。この結果は, 以前我々が初めて報告 した絶対配置と鉄除去能の関係 ${ }^{52)}$ と一致している。

\section{3-ヒドロキシモノアジンおよびN-ヒドロキシジ アジン類の生長促進活性 ${ }^{54)}$}

合成したヒドロキサム酸やカテコール類が人工シデロ フォアに成り得るかについては，数多くの論文が発表さ

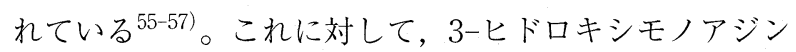
や $N$-ヒドロキシジアジン系複素環二座配位子が, 人工 シデロフォアとして機能し得るかどうか検討された例は ない。そこで，化合物 23-28(図 14)について，ヒドロ キサム酸型シデロフォア要求株であるグラム陰性菌 Aureobacterium flavescence JG-9 (ATCC No. 25091) ${ }^{58,59)}$ に対する生長促進活性能から，これらの化合物が人工シ デロフォアとなり得るかどうか評価した。

二座配位子 23-28 を含む液体培地中で A. flaves cence JG-9 を振盪培養 $\left(30{ }^{\circ} \mathrm{C}, 165 \mathrm{rpm}\right)$ し, その培地の 濁度 $\left(\mathrm{OD}_{630}\right)$ から菌体増殖率を求める方法を用いた。図 15 に培養開始 12 時間後における A. flavescence JG-9 の 二座配位子 23-28に対する濃度応答を示した。これら

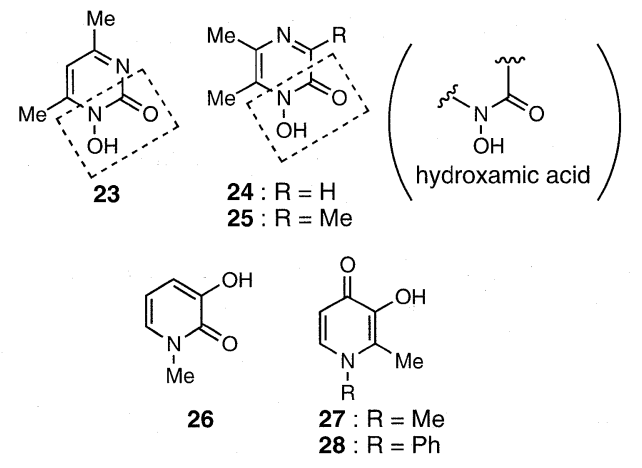

Fig. 14 Structures of 3-hydroxymonoazine- and $N$-hydroxydiazine-type heterocycles. 


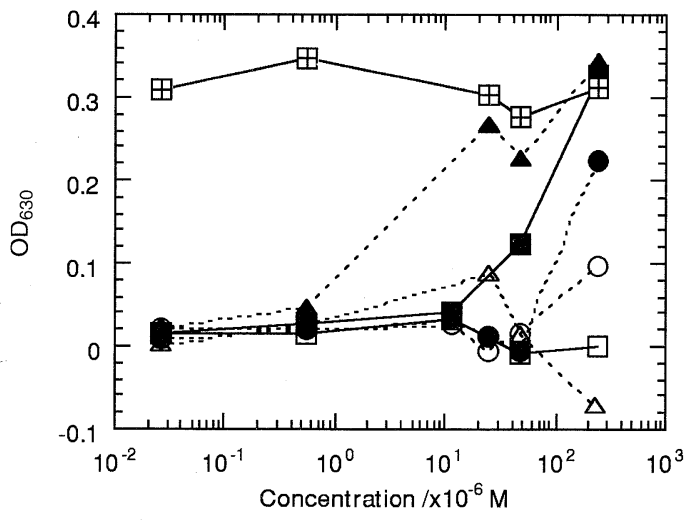

Fig. 15 Growth response of $A$. flavescens JG-9 to 23(

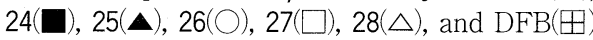
after $12 \mathrm{~h}$ incubation in ATCC medium 424 at $30{ }^{\circ} \mathrm{C}$.

の二座配位子のうち，環状ヒドロキサム酸構造を有する ピラジノン 24, 25 が良好な増殖活性を示し，それぞれ $234 \mu \mathrm{M}$ および $48.5 \mu \mathrm{M}$ で天然の DFBに匹敵する活性 を示した。同じく環状ヒドロキサム酸型構造のピリミジ ノン 23 は，234 $\mu \mathrm{M}$ で中程度の増殖活性を示した。ま た，カテコールジアニオンと等電子構造をとり得る $\alpha-$ ピリドン 26 および $\gamma$-ピリドン 28 は，それぞれ 24.2 $\mu \mathrm{M}$ および $234 \mu \mathrm{M}$ で弱いながらも増殖活性を示した。

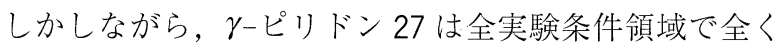
活性を示さなかった。これらの濃度条件下でさらに培養 を続けたところ，A. flavescence JG-9 の増殖曲線は図 16 のようになり，化合物 27 を除く 5 種の二座配位子は 適切な濃度条件下であれば人工シデロフォアとして機能 し得ることを初めて実証した。ここで，ヒドロキサム酸 型シデロフォア要求株であるA. flavescence JG-9 に対 して, カテコールジアニオンと等電子構造をとり得る化 合物 26 および 28 が生長促進活性を示したことは大変興 味深い。このことは，ヒドロキシアジン系複素環化合物 を配位子に用いることによって，ヒドロキサム酸型およ びカテコール型のどちらのシデロフォアレセプターに対 しても作用し得る, 汎用性の高い人工シデロフォアを構 築できることを示唆している。

\section{5. ヒドロキシモノおよびジアジン系複素環-金属錯 体の諸性質とそれらのインスリン様活性}

現代病の代表例の 1 つである糖尿病は, インスリン依 存性糖尿病 (タイプ I ; IDDM : Insulin-Dependent Diabetes Mellitus) とインスリン非依存性糖尿病（タイプII, NIDDM : Non Insulin-Dependent Diabetes Mellitus)に 大別される ${ }^{60)}$ 。NIDDM の患者の治療に関しては, 食事 療法や優れた化学療法剤が開発されている。これに対し て, IDDMの患者は, インスリンの絶対的不足が原因 のため, 毎日インスリンを皮下注射し, 血液中の血糖值

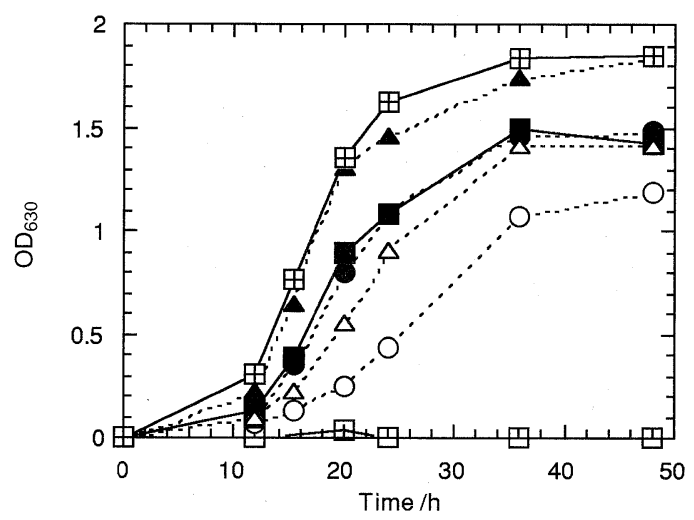

Fig. 16 Growth curves of $A$. flavescens JG-9 with 23 $234 \mu \mathrm{M}), 24(\boldsymbol{\square} ; 48.5 \mu \mathrm{M}), 25(\mathbf{\Lambda} ; 24.4 \mu \mathrm{M}), 26(\bigcirc$; $234 \mu \mathrm{M}), 27(\square ; 234 \mu \mathrm{M}), 28(\triangle$; $24.4 \mu \mathrm{M})$, and $\mathrm{DFB}($ ( $; 24.4 \mu \mathrm{M})$ in ATCC medium 424 at $30{ }^{\circ} \mathrm{C}$.

をコントロールするしかないのが現状である。また， イ ンスリンは, $5.5 \mathrm{kDa}$ のタンパク質であるため分解され 易く，経口投与できないのが欠点であり，これに代わる 新しい治療薬の開発が望まれている。ここ数年，インス リン様活性を示す経口投与可能な VO (IV)錯体が注目さ れている61,62)。また，2000年に桜井らが，亜鉛錯体に おいてもインスリン様活性を示すことを初めて明らかに した ${ }^{63)}$ ここの研究分野では，複素環を配位子として用い

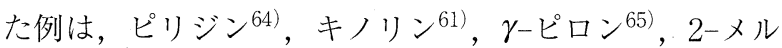
カプトピリジン $N$-オキシド66)，才キサゾリン67)，チア ゾリン ${ }^{67)}$ 程度と非常に少なく，構造-活性相関も十分明 らかにされていない。
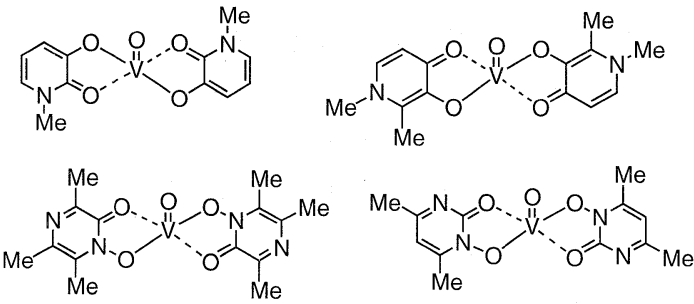

Fig. 17 Four kinds of VO(IV) complexes with hydroxyazine-type heterocycles.

当研究室では，ヒドロキシアジン系複素環の VO (IV) 錯体（図 17)がインスリン様活性を示すことを初めて明

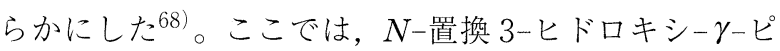
リドン類の $\mathrm{VO}$ 錯体 ${ }^{69)}$ ，および $\gamma$-ピリジンチオン類の $\mathrm{Zn}$ ( II ) 錯体とインスリン様活性 ${ }^{70)}$ について述べる。

まず， $\gamma$-ピリドン配位子 29 の VO 錯体の合成を試み た。 $\mathrm{MeOH}-\mathrm{H}_{2} \mathrm{O}$ 混合溶媒中 $\mathrm{VO}(\mathrm{acac})_{2}$ を用いて加熱環 流を行ったところ， $\mathrm{MeO}$ が結合した $\mathrm{VO}(\mathrm{V})$ 錯体 30 が 得られた。一方， $\mathrm{VO}(\mathrm{acac})_{2}$ の代わりに $\mathrm{VOSO}_{4}$ を用い $\mathrm{pH}$ を 10 に調整し同様の反応を行ったところ，目的の $\mathrm{VO}(\mathrm{IV})$ 錯体 31 を得ることができた (スキーム 5)。この 


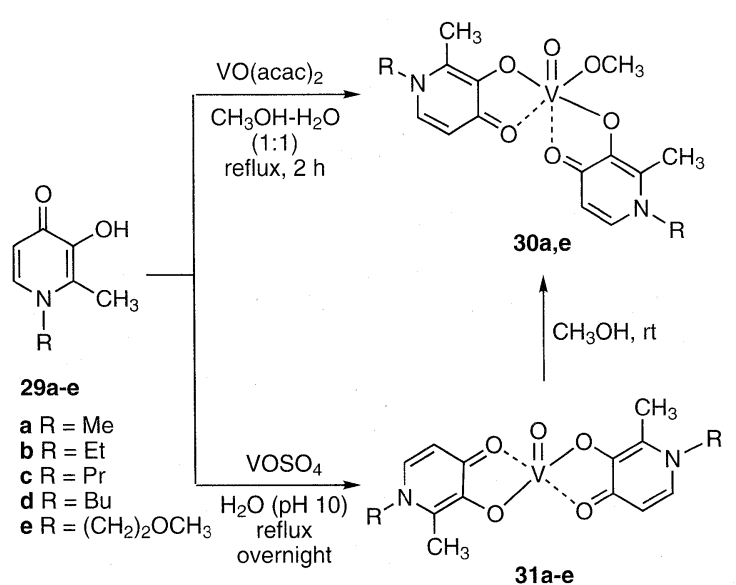

Scheme 5 Synthesis of oxovanadium complexes.

ように, $\mathrm{VO}(\mathrm{V})$ 錯体が容易に調製できたので，この錯 体の諸性質をもう少し詳細に調べることにした。

VO (IV) は常磁性であるが，VO（V)は反磁性であるた め ${ }^{1} \mathrm{H}$ NMR の測定が可能である。 VO $(\mathrm{V})$ 錯体 $30 \mathrm{e}$ で は，3.34 ppm に新たなシグナルが観測され， $\mathrm{MeO}$ が結 合していることがわかった。また，アッセイの際に用い る $\mathrm{pH}$ 領域で，本当に錯体を形成しているかを確かめる 目的で， $\mathrm{D}_{2} \mathrm{O}$ 中 $\mathrm{NaOD}$ を用いて $\mathrm{pD}$ を 8 に調整した錯 体溶液の ${ }^{51} \mathrm{~V} \mathrm{NMR}$ を, $\mathrm{VOCl}_{3}$ を外部標準物質として用 い測定した。その結果，図18に示したように，3つの シグナルが観測された。そこで配位子 $29 \mathrm{e}$ を過剩に加 え，再度スペクトルを測定したところ，-535とー503 $\mathrm{ppm}$ のシグナルが消失し， $-480 \mathrm{ppm}$ のシグナルのみ が観測された。これまでの報告例を参考に，一503 と -535 ppmのシグナルは，1個の配位子が解離した $\left[\mathrm{VO}(\mathrm{L})\left(\mathrm{D}_{2} \mathrm{O}\right)_{2}(\mathrm{OMe})\right]^{+}$と 2 個の配位子とも解離した $\left[\mathrm{VO}\left(\mathrm{D}_{2} \mathrm{O}\right)_{4}(\mathrm{OMe})\right]^{2+}$ と現時点では推測している。

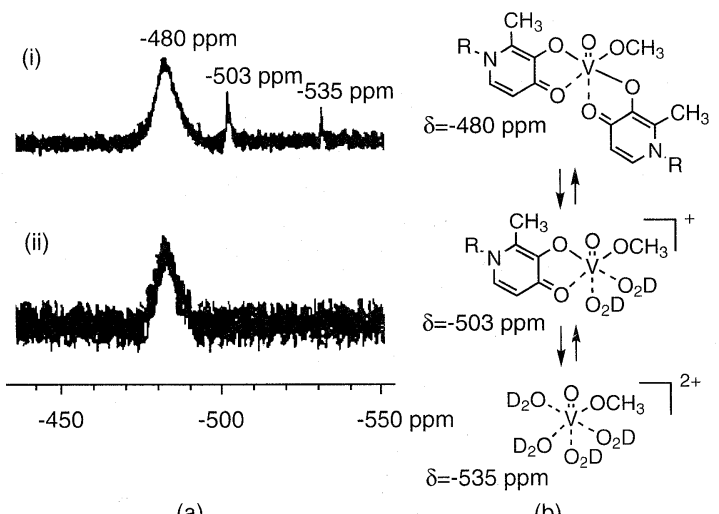

(a)

(b)

Fig. 18 (a) ${ }^{51} \mathrm{~V}$ NMR spectra of oxovanadium(V) complex (30e) in $\mathrm{D}_{2} \mathrm{O}$ at $\mathrm{pD} 8$; i) oxovanadium $(\mathrm{V})$ complex, ii) an additional ligand $(29 \mathrm{e})$. (b) The tentative assignment of observed three signals.

次に, $\mathrm{VO}(\mathrm{IV})$ 錯体の諸性質を調べた。 $\mathrm{VO}(\mathrm{IV})$ 錯体の 構造は, IRに扔いて $970 \mathrm{~cm}^{-1}$ 付近に V=O 伸縮振動に 基づく特徵的な吸収が現れたこと，および FAB MS，
元素分析，磁化率の測定から決定した。特に, VO (IV) は常磁性であるため，ESR スペクトルの測定を室温お よび液体窒素の温度で行った。VO (IV)に特徵的な 8 本 の線が観測され，単一の異性体であることがわかった。 また，表 1 に示した $\mathrm{g}$ 值と $\mathrm{A}$ 值をこれまでに報告されて いる值 ${ }^{71}$ ) と比較した結果，今回得られた錯体は， $\mathrm{VO}(\mathrm{O} 4)$ 配位形式の錯体であることがわかった。

Table 1 ESR parameters of oxovanadium (IV) complexes $(31 \mathrm{a}-\mathrm{e})$ in DMSO.

\begin{tabular}{|c|c|c|c|c|c|c|}
\hline \multirow{2}{*}{ Complex } & \multicolumn{3}{|c|}{ g-value } & \multicolumn{3}{|c|}{ A-value $\left(\times 10^{-4} \mathrm{~cm}^{-1}\right)$} \\
\hline & $\mathrm{g}_{0}{ }^{\mathrm{a}}$ & $\mathrm{g}_{/ /}$ & $g_{\perp}$ & $\mathrm{A}_{0}{ }^{\mathrm{b}}$ & $\mathrm{A}_{t /}$ & $\mathrm{A}_{\perp}$ \\
\hline $31 a^{c}$ & 1.979 & 1.947 & 1.995 & 79.43 & 153.9 & 42.12 \\
\hline $31 b^{c}$ & 1.977 & 1.953 & 1.989 & 80.14 & 153.2 & 43.61 \\
\hline $31 c^{d}$ & 1.971 & 1.950 & 1.982 & 80.58 & 159.9 & 40.91 \\
\hline $31 d^{d}$ & 1.983 & 1.951 & 1.999 & 81.12 & 162.9 & 40.19 \\
\hline $31 e^{d}$ & 1.979 & 1.950 & 1.994 & 79.59 & 162.9 & 37.94 \\
\hline
\end{tabular}

さらに, $\mathrm{VO}(\mathrm{IV})$ 錯体の電気化学的性質を知るため, サイクリックボルタモグラムを測定した(図 19)。繰り 返し掃引を行ってもほぼ同じ波形が得られたこと，㧍よ びipa/ipcの值がほぼ 1 であったことから，4価と 5 価 の間の電子移動はほぼ可逆であることがわかった。ま た，標準酸化還元電位は $300 \mathrm{mV}$ となり，3-ヒドロキシ - $\gamma$-ピロンの $\mathrm{VO}(\mathrm{IV})$ 錯体 $\left(\mathrm{E}_{1 / 2}=450-500 \mathrm{mV}\right)$ に比べ酸 化され易いこともわかった。さらに， $\Delta \mathrm{Ep}$ の值が 115 $\mathrm{mV}$ と標準の $60 \mathrm{mV}$ よかなり大きかったこと，拉よ び掃引速度の平方根を ipcに対してプロットしたところ 直線関係が得られたことより，この一電子移動は拡散律 速で進行していることもわかった。

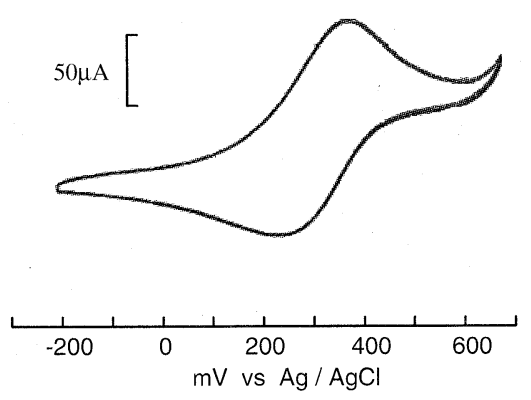

Fig. 19 Cyclic voltammogram of oxovanadium (IV) complex (31a) in $\mathrm{H}_{2} \mathrm{O}$ : $1.0 \mathrm{mM}$ complex; $0.1 \mathrm{M} \mathrm{NaCl}$; scan rate $100 \mathrm{mV} \mathrm{s}^{-1}$; a working electrode: glassy carbon; an auxiliary electrode: Pt wire; a reference electrode: $\mathrm{Ag} / \mathrm{AgCl}$.

続いて，合成した $\mathrm{VO}(\mathrm{IV})$ 錯体のインスリン様活性を を評価した。図 20 には，脂肪細胞によるグルコースの 
取り込みと, 脂肪細胞からの遊離脂肪酸の放出メカニズ ムを示した。In vitroでのインスリン様活性は, 桜井ら が開発したエピネフリンで刺激したラット脂肪細胞から の遊離脂肪酸の放出 (図 20 の左半分の経路)を $50 \%$ 抑制 する錯体の濃度 $\mathrm{IC}_{50}$ 值を，対照である $\mathrm{VOSO}_{4}$ を用いて 比較検討した ${ }^{71)}$ 。その結果, 錯体 $31 \mathrm{a}$ と $31 \mathrm{~b}$ は活性を 示さなかったが, 錯体 $31 \mathrm{c}$ と $31 \mathrm{~d}$ はマルトールの $\mathrm{VO}(\mathrm{I})$ 錯体 $\mathrm{VO}(\mathrm{ma})_{2}$ と同程度の活性を示した。この ように, O4 型の VO ( IV) 錯体では, 対照物質より優れ た活性を示す錯体は，残念ながら見出せなかった。

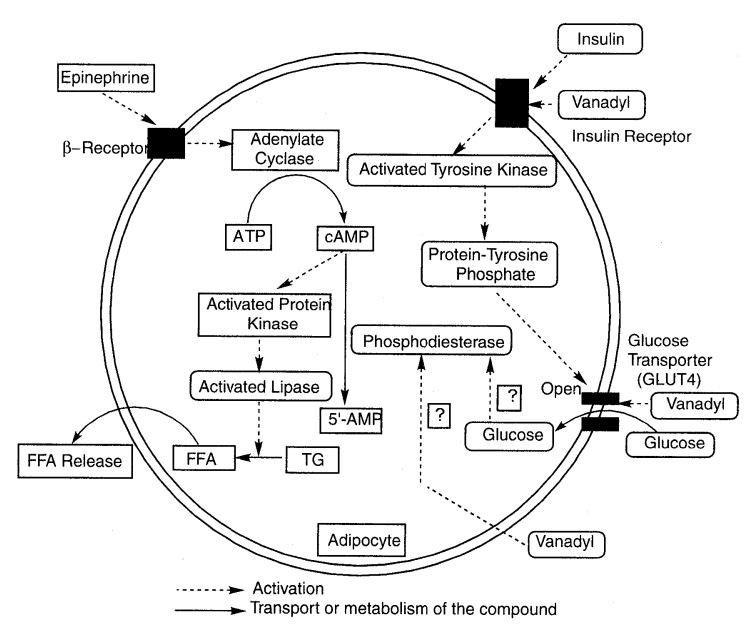

Fig. 20 Possible mechanism of glucose incorporation and FFA release form rat adipocytes.

O2S2 型の VO ( IV ) 錯体が，I 型と II 型のいずれの糖 尿病においても有効であることが動物実験から明らかに なっていたことから ${ }^{72)}$, O 2 S2 型の $\mathrm{Zn}($ II ) 錯体の合成 を試みた。 $N$-置換 3-ヒドロキシ-2-メチル-4 $(1 H)$-ピリ ジンチオン類とそれらの $\mathrm{Zn}(\mathrm{II})$ 錯体は，スキーム 6 に 従って合成した。 $\mathrm{nn}$ (II) 錯体 $34 \mathrm{~b}$ のラット脂肪細胞か らの遊離脂肪酸抑制効果は, 図 21 のように, $5 \times 10^{-5}$ から $1 \times 10^{-3} \mathrm{M}$ の濃度範囲で投与量依存性を示した （34aについては溶解性が低かったため，抑制効果を正 確に算出することはできなかった)。この結果を基に， $\mathrm{IC}_{50}$ 值を算出した結果, $N$-フェニル体の $\mathrm{Zn}($ II ) 錯体 $34 \mathrm{~b}$ では $\mathrm{IC}_{50}=0.04 \mathrm{M}$ となり，これまでに報告されてい る中で最も高い活性を示すと同時に，過去に報告された $\mathrm{Zn}(\mathrm{O} 2 \mathrm{~S} 2)$ 錯体よりも約 10 倍高い活性を示すことがわ かった。現在, I 型糖尿病のモデルである STZラット を使った動物実験を計画中である。

\section{おわりに}

以上，モノおよびジアジン系複素環化合物の特性を生 かした機能性分子への変換について最近の研究成果を中 心に紹介した。簡単な構造をもつ複素環化合物を巧く利 用しながら精密な分子設計を行うことにより，今後とも

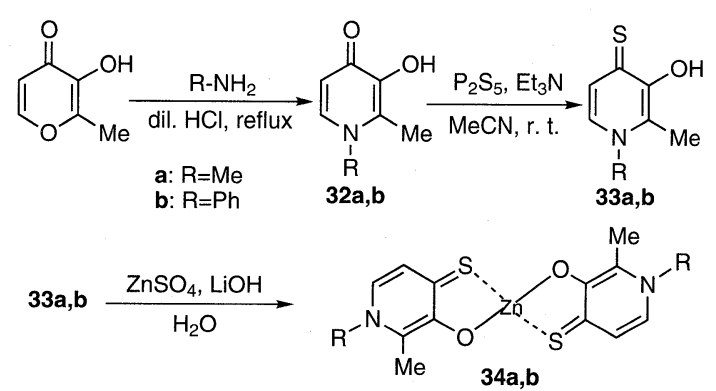

Scheme 6 Synthesis of $\mathrm{N}$-substituted 3-hydroxy-2methyl-4(1H)-pyridinethiones and their $\mathrm{Zn}$ (II) complexes.

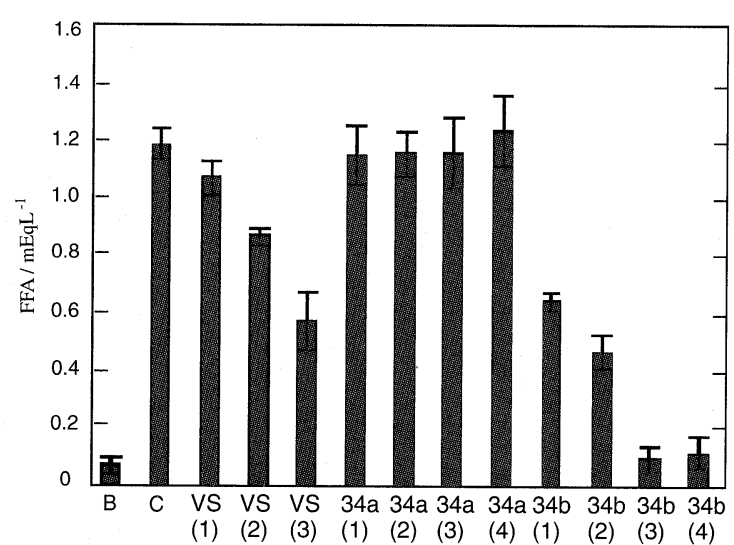

Fig. 21 Inhibitory effects of $\mathrm{Zn}(\mathrm{II})$ complexes on FFA release from rat adipocytes treated with epinephrine in the presence of $0.1 \%$ glucose: ( 1 ) $5 \times 10^{-5}$; (2) $1 \times$ $10^{-4}$; ( 3$) 5 \times 10^{-3}$; (4) $1 \times 10^{-3} \mathrm{M}$. B is blank without epinephrine and complex, $\mathrm{C}$ is control without complex, and VS is vanadyl sulfate.

新しい機能をもつ分子の創成に努めたい。

最後に, 本研究の一部は, 文部科学省科学研究費およ び日本私立学校振興 ·共済事業団学術研究振興資金の援 助を受けたものでありここに感謝する。

(2003 年 12 月 2 日受理)

\section{文 献}

1) Y. Ohkurà, Adv. Chromatogr., 29, 221 (1989)

2) M. Yamaguchi, Dojin News, No. 68, 10 (1993)

3) Y. Ohkura, H. Kai, H. Nohta, Bunseki Kagaku, 43, 259 (1994)

4) K. Iwaki, T. Bunrin, Y. Kameda, M. Yamazaki, J. Chromatogr., A, 662, 87 (1994)

5) J. Kondo, T. Imaoka, T. Kawasaki, A. Nakanishi, Y. Kawahara, J. Chromatogr., 645, 75 (1993)

6) J. Goto, M. Ito, S. Katsuki, N. Saito, T. Nambara, J. Liq. Chromatogr., 9, 683 (1986)

7) Y. Nishida, E. Itoh, M. Abe, H. Ohrui, H. Meguro, Anal. Sci., 11, 213 (1995)

8) J. Gal, A. J. Sedman, J. Chromatogr., 314, 275 (1984)

9) T. Kinoshita, Y. Kasahara, N. Nimura, J. Chromatogr., 210, 77 (1981)

10) Y. Yasaka, T. Matsumoto, M. Tanaka, Anal. Sci., 11, 295 (1995)

11) S. Einarsson, B. Josefsson, P. Moller, D. Sanchez, Anal. Chem., 59, 1191 (1987)

12) H. Spahn, D. Krauß, E. Mutschler, Pharm. Res., 5, 107 (1988); H. Spahn, P. Langguth, ibid., 7, 1262 (1990) 
13) N. Nimura, T. Kinoshita, J. Chromatogr., 352, 169 (1986)

14) R. H. Buck, K. Krummen, J. Chromatogr., 387, 255 (1987)

15) F. J. Belas, M. A. Phillips, N. R. Srinivas, R. H. Barbhaiya, I. A. Blair, Biomed. Chromatogr., 9, 140 (1995)

16) C. Vogt, A. Georgi, G. Werner, Chromatographia, 40, 287 (1995)

17) T. Toyo'oka, Yi-Ming Liu, J. Chromatogr. A, 689, 23 (1995)

18) K. Akasaka, H. Meguro, H. Ohrui, Tetrahedron Lett., 38, 6853 (1997)

19) A. Katoh, M. Takahashi, J. Ohkanda, Chem. Lett., 1996, 369

20) A. Katoh, T. Fujimoto, M. Takahashi, J. Ohkanda, Heterocycles, 50, 299 (1999); A. Katoh, T. Yoshida, J. Ohkanda, ibid., 52, $911(2000)$

21) H. D. Durst, M. Milano, Anal. Chem., 47, 1797 (1975)

22) T. Mukaiyama, R. Matsueda, M. Suzuki, Tetrahedron Lett., 1970, 1901

23) M. F. Perutz, "Mechanisms of Cooperativity and Allosteric Regulation in Proteins" Cambridge University Press, Cambridge, 1989

24) E. E. Kim, H. W. Wyckoff, J. Mol. Biol., 218, 449 (1991); I. O. Fritsky, R. Ott, R. Kramer, Angew. Chem. Int. Ed., 39, 3255 (2000)

25）T. Nabeshima, Coord. Chem. Rev., 148, 151 (1996); 鍋島達弥, 斉木利幸，秋根茂久，有合化，60,184 (2002)

26) T. Nabeshima, T. Inaba, T. Sagae, N. Furukawa, Tetraheron Lett., 31, 3919 (1990)

27) E. Graf, M. W. Hosseini, R. Ruppert, N. Kyristakas, A. D. Cian, J. Fischer, C. Estournes, F. Taulelle, Angew. Chem., Int. Ed. Engl., 34, 1115 (1995)

28) R. W. Saalfrank, A. Dresel, V. Seitz, S. Trummer, F. Hampel, M. Teichert, O. Stalke, C. Stadler, J. Daub, V. Schunemann, A. X. Trautwein, Chem. Eur. J., 3, 2058 (1997)

29) M. Albrecht, S. Kotila, Chem. Commun., 1996, 2309; M. Albrecht Chem. Eur. J., 3, 1466 (1997)

30) M. Albrecht, O. Blau, Chem. Commun., 1997, 345

31) T. Nabeshima, Y. Yoshihira, T. Saiki, S. Akine, E. Horn, J. Am. Chem. Soc., 125, 28 (2003)

32) J. Ohkanda, A. Katoh, Rev. Heteroatom Chem., 18, 87 (1998); 加藤明良，オレオサイエンス， 1, 599 (2001)

33) J. Ohkanda, H. Shibui, A. Katoh, J. Inorg. Biochem., 67, 448 (1997); idem, Chem. Commun., 1998, 375

34) A. Katoh, H. Kudo, R. Saito, J. Supramol. Chem., 2, 79 (2002)

35) J. Ohkanda, A. Katoh, Tetrahedron, 51, 12995 (1995)

36) M. Llinas, P. M. Klein, J. B. Neilands, J. Mol. Biol., 52, 399 (1970)

37) H. Benesi, J. H. Hildebrand, J. Am. Chem. Soc., 71, 2703 (1949); Y. Aoyama, M. Asakawa, Y. Matsui, H. Ogoshi, ibid., 113,6233 (1991)

38) G. Winkelman, D. van der Helm, J. B. Neilands, "Iron Transport in Microbes, Plants and Animals", VCH, Weinheim, 1987

39) W. Kaim, B. Schwederski, "Bioinorganic Chemistry: Inorganic Elements in the Chemistry of Life", John Wiley \& Sons, New York, 1991

40) G. Winkelmann, "Handbook of Microbial Iron Chelators", CRC Press, Boca Raton, 1991

41) G. Winkelmann, C. J. Carrano, "Transition Metals in Microbial Metabolism", Harwood Academic Publishers, United Kingdom, 1997

42) S. T. Callender, D. J. Weatherall, Lancet, 1980, 689; C. Kattamis, J. Fitsialos, C. Sinopoulou, Lancet, 1981, 51

43) M. R. Summers, A. Jacobs, D. Tudway, P. Perera, C. Rickett, Br. J. Haematol., 42, 547 (1979)

44) M. J. Miller, F. Malouin, "The Development of Iron Chelators for Clinical Use” ed. by R. J. Bergeron, G. M. Brittenham, CRC Press, Boca Raton, 1992, p 277

45）大神田淳子，加藤明良，有合化， 55, 524(1997)
46) A. Katoh, Y. Hikita, M. Harata, J. Ohkanda, T. Tsubomura, A. Higuchi, R. Saito, K. Harada, Heterocycles, 55, 2171 (2001)

47) A. Katoh, Y. Inoue, H. Nagashima, Y. Hikita, J. Ohkanda, R. Saito, Heterocycles, 58, 371 (2002)

48) R. C. Scarrow, P. E. Riley, K. Abu-Dari, D. L. White, K. N. Raymond, Inorg. Chem., 24, 954 (1985)

49) M. Akiyama, A. Katoh, M. Iijima, T. Takagi, K. Natori, T. Kojima, Bull. Chem. Soc. Jpn., 65, 1356 (1992)

50) P. S. Dobbin, R. C. Hider, A. D. Hall, P. D. Taylor, P. Sarpong, J. B. Poter, G. Xiao, D. van der Helm, J. Med. Chem., 36, 2448 (1993)

51) A. Shanzer, J. Libman, R. Lazar, Y. Tor, Pure Appl. Chem., 61, 1529 (1989)

52) J. Ohkanda, A. Katoh, J. Org. Chem., 60, 1583 (1995); idem, Chem. Lett., 1996, 423

53) K. N. Raymond, S. A. Nguyen, A. Crag, J. Am. Chem. Soc., 115, 6758 (1993)

54) R. Saito, K. K. Ghosh, K. Harada, A. Katoh, Yakugaku Zasshi, 122, 703 (2002)

55) T. Emery, L. Emery, R. K. Olsen, Biochem. Biophys. Chem. Commun., 119, 1191 (1984)

56) B. Lee, M. J. Miller, C. A. Prody, J. B. Neilands, J. Med. Chem., 28, 317 (1985)

57) A. Shanzer, J. Libman, R. Lazar, Y. Tor, Pure \& Appl. Chem., 61, 1529 (1989)

58) B. F. Burnham, J. B. Neilands, J. Biol. Chem., 236, 554 (1961)

59) J. B. Neilands, Struct. Bonding, 58, 1 (1984)

60) WHO, Diabetes Mellitus, Reports of a WHO Study Group, WHO Technical Report Series, 1985, p 727 and p 876

61) H. Sakurai, K. Fujii, S. Fujimoto, Y. Fujisawa, K. Takechi, H. Yasui, “ACS Symposium Series 711” ed. by A. S. Tracey, D. C. Crans, American Chemical Society, Washington, DC, 1998, p 344; H. Sakurai, A. Tsuji, "Vanadium in the Environment Part 2" ed. by J. O. Nriagu, John Wiley \& Sons, 1998, p 297; H. Sakurai, Y. Fujisawa, S. Fujimoto, H. Yasui, T. Takino, $J$. Trace Elem. Exp. Med., 12, 393 (1999); H. Sakurai, The Chemical Record, 2, 237 (2002)

62) K. H. Thompson, C. Orvig, J. Chem. Soc., Dalton Trans., 2885 (2000); K. H. Thompson, C. Orvig, Coord. Chem. Rev., 219-221, 1033 (2001)

63) Y. Yoshikawa, E. Ueda, K. Kawabe, H. Miyake, H. Sakurai, Y. Kojima, Chem. Lett., 2000, 874; E. Ueda, Y. Yoshikawa, N. Kishimoto, M. Tadokoro, N. Yanagihara, H. Sakurai, Y. Kojima, ibid., 2001, 1184; 桜井弘, 化学, 57, No. 4, 20 (2002)

64) H. Sakurai, K. Fujii, H. Watanabe, H. Tamura, Biochem. Biophys. Res. Commun., 214, 1095 (1995)

65) J. H. McNeil, V. G. Yuen, H. R. Hoveyda, C. Orvig, J. Med. Chem., 35, 1489 (1992)

66) H. Sakurai, H. Sano, T. Takino, H. Yasui, Chem. Lett., 1999, 913

67) M. Melchior, K. H. Thompson, J. M. Jong, S. J. Rettig, E. Shuter, V. G. Yuen, Y. Zhuo, J. H. McNeil, C. Orvig, Inorg. Chem., 38, 2288 (1999)

68) A. Katoh, K. Taguchi, H. Okada, M. Harata, Y. Fujisawa, T. Takino, H. Sakurai, Chem. Lett., 2000, 866; A. Katoh, K. Taguchi, K. Wakasugi, R. Saito, H. Sakurai, The $3^{\text {rd }}$ International Symposium on Chemistry and Biological Chemistry of Vanadium, 51 (2001)

69) A. Katoh, K. Taguchi, R. Saito, Y. Fujisawa, T. Takino, H. Sakurai, Heterocycles, 60, 1147 (2003)

70) A. Katoh, T. Tsukahara, R. Saito, Y. Yoshikawa, Y. Kojima, H. Sakurai, J. Inorg. Biochem., 86, 293 (2001); A. Katoh, T. Tsukahara, R. Saito, K. K. Ghosh, Y. Yoshikawa, Y. Kojima, A. Tamura, H. Sakurai, Chem. Lett., 2002, 114

71) M. Nakai, H. Watanabe, C. Fujiwara, H. Kakegawa, T. Satoh, J. Takeda, R. Matsushita, H. Sakurai, Biol. Pharm. Bull., 15, 719 81995) 
72) H. Sakurai, H. Sano, T. Takino, H. Yasui, J. Inorg. Biochem., 80, 99 (2000); S. Takeshita, I. Kawamura, T. Yasuno, C. Kimura, T. Yamamoto, J. Seki, A. Tamura, H. Sakurai, T. Goto, ibid., 85, 179 (2001)

\section{PROFILE}

加藤明良 成蹊大学工学部応用化学科・教授 〔経歴〕1982 年筑波大学大学院博士課程修 了, 1983-90 年東京農工大学工学部助手 (こ の間 1988-89 年米国マイアミ大学博士研究 員), 1990 年成蹊大学工学部工業化学科助教 授, 1995 年から現職。〔尃門〕複素環化学, 生物無機化学。[連絡先〕 e-mail:

齋藤良太 成蹊大学工学部応用化学科・助手 〔経歴〕1998 年電気通信大学大学院博士後期 課程修了, 1998-2000 年科学技術振興事業団 ERATO 井上光不斉反応プロジェクト研究 員, 2000 年から現職。〔専門〕有機合成化 学, 有機光化学。〔連絡先〕 e-mail:

\section{次号予定 \\ 特集号 有機合成化学が拓くナノサイエンスーナノ分子の構築と機能}

巻 頭 言

魔法のような分子ナノテクノロジーを目指して……….................................................

総説および総合論文

1）規則性ナノ空間の特性を活かした新しい固体触媒反応 ……...................................岩本 正和ら

2）自己組織化ナノ空間を活用した空孔制御反応 ……..........................................藤田 誠ら

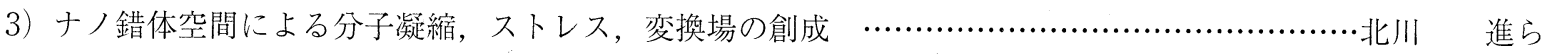

4）精密金属集積高分子材料の創製と応用 …….........................................................元 公寿ら

5）新しい自己組織化材料：一次元金属錯体を主鎖とするナノワイヤーの開発…………………君塚 信夫

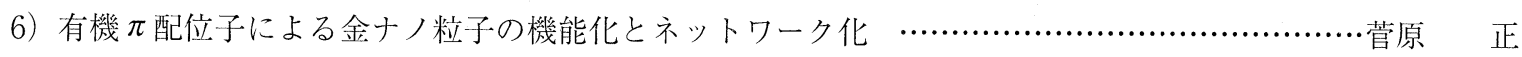

7）超分子・高分子ナノ構造体の合成と機能 ……………………………....................相田 卓三ら

8）超分子ポリマーの構築と機能 ………............................................................ 明

9) Photomechanical Effects in Azobenzene-Containing Polymer Systems ….........................池田 富樹ら

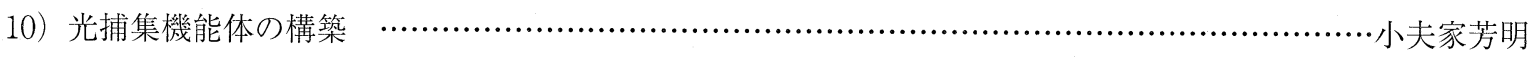

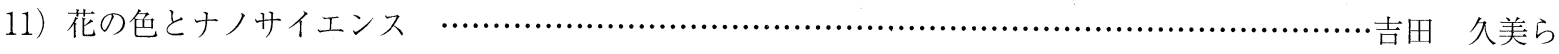

12）天然ナノ分子 タンニンーその構造と機能 ……...............................................吉田 隆志ら

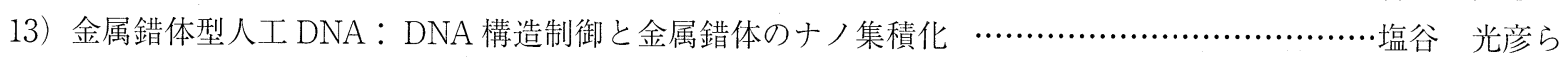

14）ナノファイバーを利用した再生医療……….........................................................北薗 英一ら

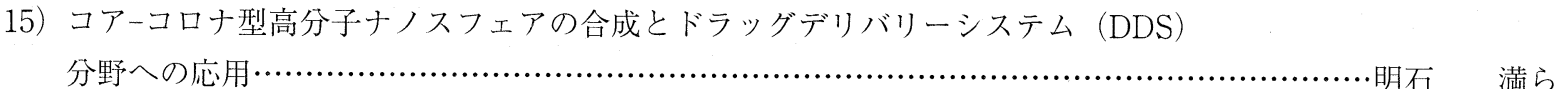

16）糖クラスターを用いるジーンデリバリー：ウイルスサイズ $(50 \mathrm{~nm})$ を目指して ……………青山 安宏

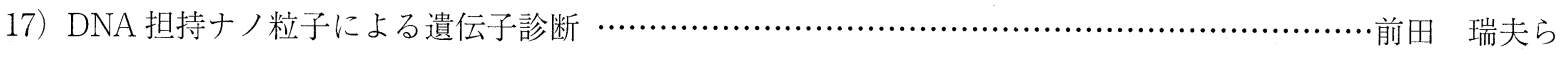

ラウンジ

化学分野におけるナノテクノロジービジネス推進協議会に対する期待………….....................小林 勝

新しい合成ほか 